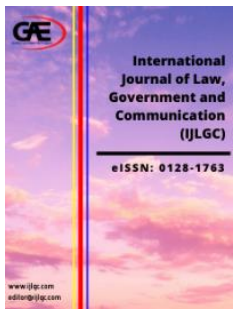

\author{
INTERNATIONAL JOURNAL OF LAW, \\ GOVERNMENT AND COMMUNICATION \\ (IJLGC) \\ www.ijlgc.com
}

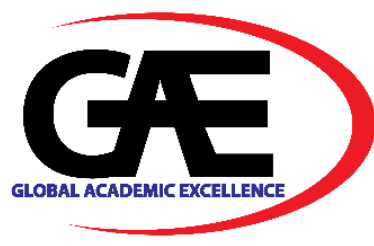

\title{
CHILD CARE OR CHILD SCARE: ENHANCING THE LEGAL REQUIREMENTS ON HEALTH AND SAFETY IN CHILD CARE CENTRES LAWS AND REGULATIONS IN MALAYSIA
}

\author{
Mashitah Abdul Mutalib ${ }^{1 *}$, Nik Salida Suhaila Nik Saleh ${ }^{2}$, Nurfadhilah Mohamad $\mathrm{Ali}^{3}$ \\ $1 \quad$ Faculty of Syariah and Law, Universiti Sains Islam Malaysia \\ Email: mashitahmutalib@usim.edu.my \\ 2 Faculty of Syariah and Law, Universiti Sains Islam Malaysia \\ Email: salida@usim.edu.my \\ 3 Faculty of Syariah and Law, Universiti Sains Islam Malaysia \\ Email: fadhilah.a@usim.edu.my \\ * Corresponding Author
}

\section{Article Info:}

Article history:

Received date: 23.03.2021

Revised date: 04.04.2021

Accepted date: 14.06.2021

Published date: 15.06.2021

\section{To cite this document:}

Mutalib, M. A., Nik Saleh, N. S. S., \& Ali, N. M. (2021). Child Care Or Child Scare: Enhancing The Legal Requirements On Health And Safety In Child Care Centres Laws And Regulations In Malaysia. International Journal of Law, Government and Communication, 6 (24), 177-185.

DOI: 10.35631/IJLGC.6240011.

This work is licensed under CC BY 4.0

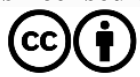

\begin{abstract}
:
Health and safety are the required legal requirements that need to be regulated in-laws and regulations of child care centres. These legal requirements are categorised as structural quality features which are often translated into laws and regulations in ensuring quality child care for children. This paper examines the question of whether the health and safety legal requirements necessitate improvements in the legislative framework of Malaysian child care. The laws and regulations in Malaysia on health and safety requirements as stated in the Child Care Centre Act 1984 and Child Care Centre Regulation 2012 are evaluated according to the relevant sections and regulations. Recommendations are made in enhancing laws and regulations in child care centres in Malaysia regarding health and safety. The qualitative method was used in this study using document analysis especially the related laws in Malaysia. Cross-reference to other jurisdictions' laws and regulations such as Australia and Singapore was also conducted. In conclusion, enhancement on health and safety features need to be made especially with regards to knowledge on child protection law amongst child care providers, prohibition of employment, laws, and regulations on incidents, injury and trauma, and medicine and drugs administration.
\end{abstract}

Keywords:

Child Care Centres, Health And Safety, Structural Quality, Child 


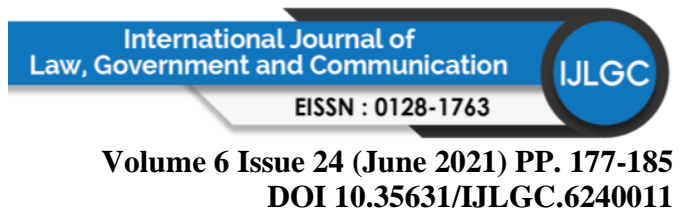

\section{Introduction}

As children may be exposed to various risks such as injuries, infectious diseases, and even physical and emotional abuse, child care should always offer high quality care and education with high emphasis on health and safety. It is mentioned that when there is good health and safety element in child care, children will benefit as there would be early detection of health problems, lower risks of illnesses and special treatment for special needs children (Crowley et al., 2013). Otherwise, the health problems of an ill child may spread to his or her parents and the staff at the child care centre. As a result, this will cause lower productivity as they have to be absent from work. The occupational health and safety of the child care providers should also be given high consideration by the management of the child care centres as their health and safety also affect the children (Hanafi \& Ismail, 2014).

Health and safety may be predictors of quality which also are often listed as an evaluative criterion in measuring quality. This criteria if well taken care of will lead to lower rates of infectious diseases, respiratory illnesses and playground injuries among children (Vandell \& Wolfe, 2000). Amongst hygienic and safe practices are proper hands washing after changing diapers, cleanliness in preparing food, and others. Besides that, preparing a safe environment includes protecting child care from toxic materials, ensuring premises are covered and arranging emergency plans (Blasberg et al., 2019).

As far as Malaysian child care is concerned, although there are efforts in promoting health and safety in child care especially looking at the Malaysia National Child Care Quality Standards which underline nutrition and health and safety as amongst the standards that should be observed by child care operators in Malaysia, the question is whether the minimum requirements set by the regulations in child care in Malaysia is adequate or the regulations illustrate requirements below the basic level of acceptable care.

It has been mentioned by Datin Paduka Chew Mei Fun that amongst the violations of laws and regulations that have been committed by child care centres, to the point that action has to be taken against them by deregistering their centres, include the condition of the premises which have been deemed to be unsafe for the children; these child care operators have not abide by the safety orders made by the authorities (BERNAMA, 2015).

Furthermore, the raising cases of child abuse are alarming. An example of a child abuse cases in child care centres has involved an infant who suffered from severe head bleeding which has affected her eyes. The child care provider, was found guilty of shaking the infant so hard and was ordered to pay a compensation of RM40, 000 to the parents or in the event of the failure to pay the compensation, she has to serve 12 months of imprisonment. This was dealt under Section 31 (1) (a) of Child Act 2001 where the maximum fine is RM 50,000 or imprisonment of 20 years or both (Zulkifli, 2015). In June 2021, two child care providers were investigated for abuse case in child care centres. This case involved one year and eight months and another child aged one year and nine months. Both victims were under treatment in the hospital (Zack, 2021).

In relation to that, children may also be injured due to any negligence acts. These act may cause child care injuries. Child care injuries may due to child factors such as falls, collisions, thrown toys or bites. In addition, children may also be injured due to environmental factors such as wet floors, non-child-friendly furniture, sharp objects and so on (Lang, 2009). These injuries 


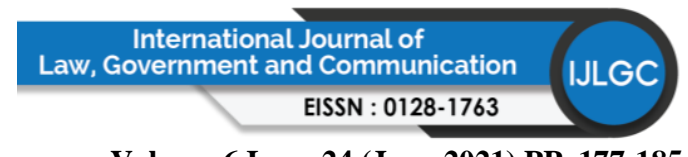

Volume 6 Issue 24 (June 2021) PP. 177-185

DOI 10.35631/IJLGC.6240011

though sometimes do occur, but with proper supervision, the injuries are predictable and avoidable (Nabiha et al., 2015).

\section{Improvement on Malaysian Child Care Provisions on Health and Safety Features}

It is interesting to note that there are three standard elements in Australia's legislations on health and safety, the first promotes the health of the children, the second on healthy eating and physical activities and the third addresses the protection of a child (Australian Children's Education and Care Quality Authority, 2017). As a comparison, Malaysia do regulate on promoting the health of the children, healthy eating, and physical activities. However, Malaysia's laws and regulations lack the provision for child protection in its legislation, be it in the Act or in the Regulations.

Moreover, one of the significant parts that should be highlighted in the health and safety provisions is the child abuse element. This is one of the indicators listed by Fiene (2002). Abuse can be in the form of physical abuse or sexual abuse. Physical abuses sometimes result from excessive disciplinary measures put upon the children. That is why there is a need to have provisions on prohibiting excessive discipline measures in child care centres. Furthermore, it is suggested that abuses may be caused by the lack of support provided to the child care providers (Fiene, 2002). Therefore, in strengthening the indicator on health and safety, there is a need to strengthen other indicators including staffing issues which include ratio, group size, and conducive environments so as to assist them to deliver their job effectively and to be free from any pressures which may cause untoward acts that are harmful to the children. Besides that, there is also a need to legislate on how to deal with abuse cases such as to do the report, liaising with the doctors or nurses and conveying information to the parents. Child care providers need to be aware of their legal responsibilities to report any abuse cases that occur. As benchmark, examples of provisions as in Singapore and Australia may be taken consideration. Regulation 17 of the Singapore Child Care Centres Regulation 2012 regulates on this by stating:

'Every licensee shall cause to ensure that the staff shall not administer the following disciplinary measures: (a) any form of corporal punishment, including the following: (i) striking a child, directly or with any physical objects; (ii) shaking, shoving, spanking or other forms of aggressive contact; and (iii) requiring or forcing the child to repeat physical movements; (b) harsh, humiliating, belittling or degrading responses of any kind, including verbal, emotional and physical; (c) deprivation of meals; or $(d)$ isolation and physical restriction of movements'.

As can be seen in Regulation 17 of the Singapore regulations, there is prohibition of corporal punishment, disciplinary measures, striking directly using hands or any objects, shaking, shoving, spanking or forcing the children to do repetitive physical movements, belittling or harsh responses, depriving meals, and restricting the children's movements. However, these offences in Singapore have only warranted the issuance of warning letters to warn the offender from repeating the actions.

A heavier penalty is practised by Australia when Section 166 of Education and Care Services National Law 2010 highlights the penalty of offence to use inappropriate discipline is $\$ 100000$ in individual case, or $\$ 50000$ in any other case. The Section states that, 'The approved provider of an education and care service must ensure that no child being educated and cared for by 


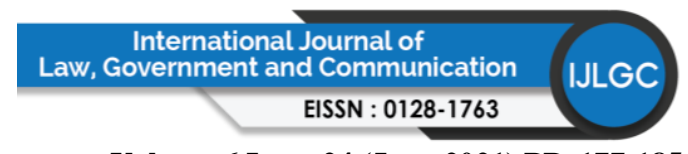

Volume 6 Issue 24 (June 2021) PP. 177-185

DOI 10.35631/IJLGC.6240011

the service is subjected to $(a)$ any form of corporal punishment; or $(b)$ any discipline that is unreasonable in the circumstances. Penalty: $\$ 10$ 000, in the case of an individual. $\$ 50000$, in any other case'.

This is with regard to the approved provider himself should he fail to ensure that the children in his child care centres are protected from being inflicted with inappropriate disciplinary measures. When the offence is subjected to a nominated supervisor, staff member, volunteer, or family day care educator, the penalty is $\$ 10000$. Besides the protection form inappropriate disciplinary measures, there is also a provision in Australia on the protection of children from harm and hazards under Section 167 whereby the failure to adhere to this shall incur a penalty of $\$ 100000$ in the case of an individual or \$50 000 in any other case. Section 167 states that, 'The approved provider of an education and care service must ensure that every reasonable precaution is taken to protect children being educated and cared for by the service from harm and from any hazard likely to cause injury. Penalty: $\$ 10000$, in the case of an individual. $\$ 50$ 000, in any other case'.

Malaysia too has this under Regulation 42 where it states:

(1)For the purpose of instilling discipline among the children, an operator, a manager, a supervisor, a child care provider, a registered child care provider or an employee shall not(a) use harsh language inappropriate to be used in the presence of a child; and (b) take corrective measures on a child which amount to an abuse either emotionally or physically.(2)An operator, a manager, a supervisor, a child care provider, a registered child care provider or an employee who fails to comply with subregulation (1) commits an offence and shall on conviction be liable to a fine not exceeding one thousand ringgit or to imprisonment for a term not exceeding six months or to both'.

Thus, the operator, manager, supervisor, child care provider are prohibited from speaking and using harsh language when the children are around. Besides that, in disciplining the children, they shall not take action which will lead to emotional or physical abuse. Violating this regulation shall amount to an offence punishable with a fine not exceeding RM 1,000 or imprisonment not exceeding six months or both. This is what can be seen in a case where the mother provided a cane for the purpose of disciplining her child but it turned out that the child was badly beaten (Dass, 2015). The child minder claimed that she had to beat the child using the cane to discipline her. However, the mother was shocked to see the scars and injuries on several parts of her child's body. She then reported the matter to the police in Johor.

\section{Obligation of The Child Care Providers to Have Knowledge on Child Protection Law}

Malaysia already has provision on the limits that a child care provider should be aware of when disciplining a child. However, Malaysia should insert the provision on the obligation of the child care providers to have knowledge on child protection law. Therefore, they are aware that for instance in the event of negligence or abuse, they may be subjected to punishment under Section 31 (1) (a) of Child Act 2001 where the punishment is greater than those provided in CCCA 1984. It is well stated in Regulation 84 of Australia's National Regulations that the provider or an operator of the centre must ensure that his staffs are aware of the child protection law in terms of the gist and the how it applies to them. Regulation 84 states that, 'The approved provider of an education and care service must ensure that the nominated supervisor and staff members at the service who work with children are advised of - (a) the existence and 


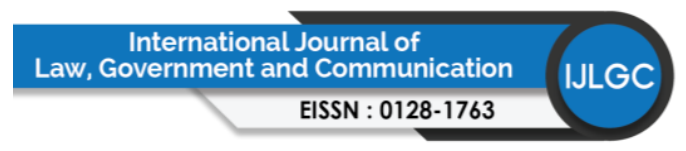

Volume 6 Issue 24 (June 2021) PP. 177-185

DOI 10.35631/IJLGC.6240011

application of the current child protection law; and (b) any obligations that they may have under that law. Penalty: \$1000'.

It is noted in the guide for National Laws and Regulations (Australian Children's Education and Care Quality Authority, 2017) that this awareness may be instilled through trainings made regularly or in-house seminars, or even training through an online medium.

\section{Employment Issues}

It would also be better if Malaysia could specify clearly as has been done by Singapore in Regulation 26 on prohibition of employment. Regulation 26 (a) (i) prohibited employment of those who was involved with child abuse or child neglect when it states:

'The Director may, in his discretion, prohibit the licensee of any child care centre from employing any person as staff of that child care centre if - (a) the person to be employed has been convicted of - (i) any offence under section 5, 6, 7, 11, 12 or 13 of the Children and Young Persons Act (Cap. 38), or any other offence involving child abuse or child neglect; (ii) any offence under Part XI of the Women's Charter (Cap. 353)'.

Therefore, the precautionary steps have been taken before the employment is made in order to prevent more unwanted incidents of abuse and neglect involving children in child care centres.

Besides of investigating the history of any child abuse conviction, the mental health of the child care providers also need to be ascertained. The working condition should be accommodating to child care providers in supporting their psychological and emotional health (Linnan et al., 2017). Their welfare needs to be well taken care of by avoiding excessive low wages, long hours working and inadequate health benefits.

\section{Laws and Regulations on Incidents, Injury and Trauma}

Furthermore, in the application of the standards on 'protection of the children' there should also be laws and regulations on incidents, injury and trauma especially on how the child care providers are required to deal with these matters. It is quite alarming when it is found that there is no regulation in Malaysia presenting guidance on how to handle injuries, illness or trauma suffered by the children.

There should be specific procedures that are to be followed by the child care providers when the children suffer injuries, illness or trauma. They must keep a record on details of the accidents, or illness, actions that are taken such as medication that is given to the children, details of the witness, and details of any person who is notified. This record must then be signed 


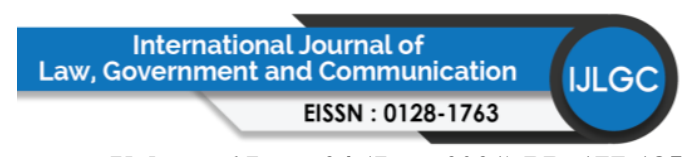

Volume 6 Issue 24 (June 2021) PP. 177-185

DOI 10.35631/IJLGC.6240011

by the person recording it. This is well written under Regulation 851,862 and 873 of the Australia Education and Care Services National Regulations 2012. It is interesting to note that this record shall be kept and stored confidentially until the child is 25 years of age (Australian Children's Education and Care Quality Authority, 2017).

In Singapore too there is a provision under Regulation 21 to immediately report to the Director when there is reasonable cause for suspicion of any child abuse. Regulation 21 states that, 'The licensee of a child care centre who has reasonable cause to suspect any case of child abuse shall immediately report it to the Director'.

In addition, Regulation 11(4) also regulates the child care provider on the procedures in the event of serious accident, illness or death when it highlights:

'Where a serious accident, illness or death occurs to a child, the licensee shall forthwith - (a) obtain all necessary emergency medical assistance; (b) notify the parents or guardian of the child; (c) maintain proper record of the occurrence; and $(d)$ notify the Director within 24 hours of its occurrence and if a public holiday falls during that period, on the day following the public

\footnotetext{
${ }^{1}$ Regulation 85 of Australia Education and Care Services National Regulations 2012 requires procedures to be followed in the time of incident, injury, trauma and illness by stating that, 'The incident, injury, trauma and illness policies and procedures of an education and care service required under regulation 168 must include procedures to be followed by nominated supervisors and staff members of, and volunteers at, the service in the event that a child - (a) is injured; or (b) becomes ill; or(c) suffers a trauma'.

${ }^{2}$ Regulation 86 of Australia Education and Care Services National Regulations 2012 obliges notification to be made to parents as soon as possible in the time of emergency by stating that, 'The approved provider of an education and care service must ensure that a parent of a child being educated and cared for by the service, or if a parent cannot be immediately contacted, an authorised emergency contact for the child is notified as soon as practicable, but not later than 24 hours after the occurrence, if the child is involved in any incident, injury, trauma or illness while the child is being educated and cared for by the education and care service. Penalty: \$2000'.

${ }^{3}$ Regulation 87 of Australia Education and Care Services National Regulations 2012 explains on the procedures of record keeping of any incident, injury, trauma and illness by highlighting that, '(1) The approved provider of an education and care service must ensure that an incident, injury, trauma and illness record is kept in accordance with this regulation (2) A family day care educator must keep an incident, injury, trauma and illness record in accordance with this regulation (3) The incident, injury, trauma and illness record must include - (a) details of any incident in relation to a child or injury received by a child or trauma to which a child has been subjected while being educated and cared for by the education and care service or the family day care educator, including - (i) the name and age of the child; and(ii) the circumstances leading to the incident, injury or trauma; and (iii) the time and date the incident occurred, the injury was received or the child was subjected to the trauma; $(b)$ details of any illness which becomes apparent while the child is being educated and cared for by the education and care service or the family day care educator including - (i) the name and age of the child; and (ii) the relevant circumstances surrounding the child becoming ill and any apparent symptoms; and (iii) the time and date of the apparent onset of the illness; (c) details of the action taken by the education and care service or family day care educator in relation to any incident, injury, trauma or illness which a child has suffered while being educated and cared for by the education and care service or family day care educator, including - (i) any medication administered or first aid provided; and (ii) any medical personnel contacted; $(d)$ details of any person who witnessed the incident, injury or trauma; ( $e$ ) the name of any person - $(i)$ whom the education and care service notified or attempted to notify, of any incident, injury, trauma or illness which a child has suffered while being educated and cared for by the education and care service or family day care educator; and (ii) the time and date of the notifications or attempted notifications; $(f)$ the name and signature of the person making an entry in the record, and the time and date that the entry wasmade.(4) The information referred to in subregulation (3) must be included in the incident, injury, trauma and illness record as soon as practicable, but not later than 24 hours after the incident, injury or trauma, or the onset of the illness'.
} 


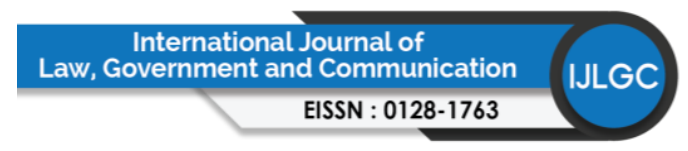

Volume 6 Issue 24 (June 2021) PP. 177-185

DOI 10.35631/IJLGC.6240011

holiday. (5) When a child dies, the licensee shall cause to immediately notify the police of the death'.

Emergency medical measures should be taken, parents should be notified, record of the incidents should be well kept, and the Director too should be notified within 24 hours. In the event of death of a child, the child care provider must immediately report the matter to the police.

There should be good procedural steps that lay down the steps to be taken when there is any abuse case. This is for the authorities to tackle the matters accordingly. Uploading this in the social media for instance is not a solution though viral news will get quick attention by the authorities concerned as it will become public interest. As explained by Datin Paduka Chew Mei Fun, Deputy Minister of Family, Women and Community Development, making the news viral in social media will put pressure on the victims and the parents if the cases involved infants (BERNAMA, 2016).

\section{Medicine and Drugs Administration}

Furthermore, another Regulation that should be revised by the Malaysian legislative system pertains to medicine and drugs administration. There should be proper regulation on how medicine or drugs are administered to children. The record should have the name, dosage guide, name of the one who administer the medicine or drugs and the time. This is how Singapore regulates this matter under Regulation 134. Australia's regulations detail on medical conditions as well for there is the obligation to have a policy on managing medical conditions. This is with regards to managing children with specific health issues or allergy by planning to minimise risks. This requires good communication between the staff and the parents. These are regulated under Regulation 90 to 91 of Australian Education and Care Services National Regulations. Meanwhile further clarification on administration of medication is set out in Regulation 92 to 96 such as the need for parents' authorisation, and procedures as to the dosage, storage and so on.

\section{Conclusion}

Therefore, in enhancing the legal requirements on health and safety, a few important matters need to be given attention. Malaysia should focus on enhancing child protection provision. This includes provisions to prohibit any maltreatments or abuse of children by child care providers. There is a need to ascertain that child care providers and operators are free from any involvement in cases of abuse. Besides that there is the practise by Australia, clearly stipulated in Regulation 84 of Education and Care Services National Regulations 2012, for child care providers to have knowledge on child protection. This provision should be exampled by Malaysia as knowledge of the laws and punishments may be an effective preventive tool in

\footnotetext{
${ }^{4}$ Regulation of Singapore Child Care Centres Regulation 2012 states that, '(1) Every child care centre shall ensure that - (a) no medicine or drug is to be administered to a child unless otherwise prescribed by a registered medical practitioner, or in accordance with the written instructions of the parent or guardian of the child; (b) all containers of any medicines or drugs to be administered to a child are clearly labelled with the child's name and instructions for administration of the medicines or drugs; and (c) all medicines or drugs are to be kept out of reach ofchildren. (2) The licensee shall cause a proper written record to be maintained for administration of medicine or drugs in relation to each child at the child care centre. The record shall include (a) the name of the child; (b) the name of medicine or drugs administered; (c) the dosage of medicine or drugs administered; $(d)$ the name of person who administered the medicine or drugs; $(e)$ the time and date of administration; and $(f)$ the manner of administration'.

Copyright $\odot$ GLOBAL ACADEMIC EXCELLENCE (M) SDN BHD - All rights reserved
} 


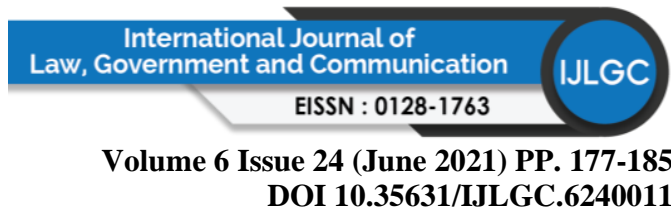

deterring unwanted incidents against the children. In addition, procedures in handling abuse cases or emergencies should also be scrutinised further so as to provide guidance for the child care provider. Furthermore, provisions on medical and drugs may also be further improved.

It is a relief to see that the government will review the standard operating procedures for child care centres in responding reactively to abuse cases which keep happening in child care centres (Malay Mail, 2021). Nevertheless, enhancement on the provisions in the statutes must be given attention. The review in enhancing the existing legislation need to be conducted expeditiously (Sulaiman et al., 2017). This is one of the effective ways in curbing child abuse in child care centres through preventive approach. Instead of using reactive approach in responding to the abuse issues in child care centres, prevention approach through strengthening the statutes need to be prioritised.

Therefore, there is an urgent need to review the current legislation in the effort to upgrade the services offered by child care centres.

\section{References}

Australian Children's Education and Care Quality Authority. (2017). Guide to the Education and Care Services National Law and the Education and Care Services National Regulations 2011 (Issue February).

BERNAMA. (2015). Tak Ikut Akta Asuhan. MyMetro. https://www.hmetro.com.my/mutakhir/2016/10/176622/tak-ikut-akta-asuhan

BERNAMA. (2016). Lapor Kes Dera, Bukan Viralkan. MyMetro. https://www.hmetro.com.my/mutakhir/2016/10/176622/tak-ikut-akta-asuhan

Blasberg, A., Bromer, J., Nugent, C., Porter, T., Shivers, E. M., Tonyan, H., Tout, K., \& Weber, B. (2019). A Conceptual Model for Quality in Home-Based Child Care (Issue March). https://www.acf.hhs.gov/sites/default/files/opre/cceepra_hbcc_conceptual_model_508 b.pdf

Crowley, A. A., Jeon, S., \& Rosenthal, M. S. (2013). Health and Safety of Child Care Centers : An Analysis of Licensing Specialists 'Reports of Routine, Unannounced Inspections. 103(10), 52-58. https://doi.org/10.2105/AJPH.2013.301298

Dass, M. V. (2015). Rotan Anak Orang Sampai Berbirat. Mymetro.

Fiene, R. (2002). 13 Indicators of Quality Child Care : Research Update.

Hanafi, Z., \& Ismail, S. N. (2014). Inside The Child Care Center: How to Ensure Quality Child Care Practices. International Journal of Education, 8(1).

Lang, M. (2009). Health implications of children in child care centres Part B: Injuries and infections. In Paediatrics \& Child Health (Vol. 14, Issue 1, pp. 40-43). https://doi.org/10.1519/00126548-200204000-00016

Linnan, L., Arandia, G., Bateman, L. A., Vaughn, A., Smith, N., \& Ward, D. (2017). The health and working conditions of women employed in child care. International Journal of Environmental Research and Public Health, 14(3). https://doi.org/10.3390/ijerph14030283

Malay Mail. (2021). KPWKM to review SOPs in childcare centres to prevent child abuse. https://malaysianews.today/2021/03/27/1961621/

Nabiha, G., Hayati, K., \& Hejar, A. (2015). A Protocol on Factors Influencing Safety Practices for Injury Prevention Amongst Children in Day-Care Centres in Selangor and Putrajaya,2015. International Journal of Public Helath and Clinical Services, 1(2), 191-203. 
Volume 6 Issue 24 (June 2021) PP. 177-185

DOI 10.35631/IJLGC.6240011

Sulaiman, Y., Perumal, S., Ghani, N. H. A., Mat, N. K. N., Ismail, M. Y. S., \& Musa, R. (2017).

A conceptual paper on safety and quality assurance model in Malaysian child care centres. International Journal of Economic Research, 14(19), 333-340.

Vandell, D. L., \& Wolfe, B. (2000). Child Care Quality: Does It Matter And Does It Need to Be Improved? Institute for Research on Poverty Special Report, 78(78). http://www.ncbi.nlm.nih.gov/sites/entrez?Db=pubmed\&DbFrom=pubmed\&Cmd=Lin $\mathrm{k} \&$ LinkName $=$ pubmed_pubmed\&LinkReadableName $=$ Related

Articles\&IdsFromResult=11081694\&ordinalpos=3\&itool=EntrezSystem2.PEntrez.Pu bmed.Pubmed_ResultsPanel.Pubmed_RVDocSum\%5Cnhttp://www.ncb

Zack, J. (2021). Two childcare centre workers arrested over suspected child abuse cases. The Star Online. https://www.thestar.com.my/news/nation/2021/06/11/two-childcarecentre-workers-arrested-over-suspected-child-abuse-cases

Zulkifli, S. (2015). Bayi Cacat Digoncang. Mymetro. 